\title{
Water Pollution and Environmental Governance of the Tai and Chao Lake Basins in China in an International Perspective
}

\author{
Lei Qiu',2,3, Meine Pieter Van Dijk ${ }^{3 *}$, Huimin Wang1,2 \\ ${ }^{1}$ State Key Laboratory of Hydrology-Water Resources and Hydraulic Engineering, Hohai University, Nanjing, \\ China \\ ${ }^{2}$ Research Institute of Management Science, Business School, Hohai University, Nanjing, China \\ ${ }^{3}$ UNESCO-IHE Institute for Water Education, Delft, The Netherlands \\ Email: ${ }^{*}$ mpvandijk@iss.nl
}

Received 12 May 2015; accepted 18 July 2015; published 21 July 2015

Copyright (C) 2015 by authors and Scientific Research Publishing Inc.

This work is licensed under the Creative Commons Attribution International License (CC BY).

http://creativecommons.org/licenses/by/4.0/

(c) (i) Open Access

\section{Abstract}

The Tai and Chao Lake basins are currently facing a serious water pollution crisis associated with the absence of an effective environmental governance system. The water pollution and the water governance system of the two basins will be compared. The reasons for water pollution in both basins are similar, namely the weak current water environmental governance system cannot deal with the consequences of the rapidly growing economy. China's water governance system is a complicated combination of basin management with both departmental management and regional management. There is an absence of legal support and sound coordination mechanisms, resulting in fragmented management practices in the existing water environmental governance system. A comparison is made for the Tai and Chao Lake basins and Canada, France, the United Kingdom and the United States. Based on China's present central-local governance structure and departmental system, an integrated reform of basin level and water environmental governance in China should learn from international experiences. The reforms could consist of improved governance structures, rebuilding authoritative and powerful agencies for basin management, strengthening the organizational structure of the basin administrations, improving legislation and regulatory systems for basin management and enhancing public participation mechanisms.

\section{Keywords}

Water Pollution, Water Governance, Environmental Governance, Basin Management, Tai Lake

${ }^{*}$ Corresponding author.

How to cite this paper: Qiu, L., Van Dijk, M.P. and Wang, H.M. (2015) Water Pollution and Environmental Governance of the Tai and Chao Lake Basins in China in an International Perspective. Journal of Water Resource and Protection, 7, 830-842. http://dx.doi.org/10.4236/jwarp.2015.710067 


\section{Basin, Chao Lake Basin, Participation}

\section{Introduction}

The five largest freshwater lakes in China-Poyang Lake, Dongting Lake, Tai Lake, Chao Lake, and Hongze Lake-are all located in the middle and lower reaches of Yangtze River and Huai River. The region has a high population density and has shown rapid economic development. These five lakes are major freshwater storage areas, and play an important role for maintaining a regional ecological balance, providing freshwater resources, preventing floods, diminishing environmental pollution, etc. However, with rapid industrialization and urbanization, serious environmental problems manifest themselves in these five freshwater lakes. Especially the Tai and Chao Lake areas have been listed as objects of Water Pollution Control and Management Projects by the State Council of China as long ago as 1996.

The Tai Lake basin is the core of Yangtze River Delta region, which is one of the most developed areas in China. Since the 1980s, the water quality level of Tai Lake basin on average decreased one level each decade [1]. A lot of water pollution prevention and control works in Tai Lake have been undertaken; however, the works still lag behind the economic and social development of the Tai Lake basin and water pollution has exceeded the environmental capacity. Water pollution prevention and control in the Tai Lake Basin has become the focus of the state environmental protection work with an important demonstration effect for other Chinese lakes.

The Chao Lake basin is located in the centre of the Anhui Province. Economic activities are less developed and the urbanization level is lower in this basin. Currently the most serious issue of Chao Lake is water pollution. At the end of the 11th Five-Year Plan for National Economic and Social Development (2006-2011), the water quality of Chao Lake was Class V, and the whole lake had a mild level of eutrophication.

There is a tendency in China to consider water issues as technical problems which can be solved by building dams or sluices. However, water problems are not just technical problems. Water governance is important to provide an integrated approach to the real water issues, which is necessary because of the interrelated nature and complexity of issues like water availability, water quality and flood problems and the need to manage and coordinate the processes for identifying, sharing and solving these problems in a multidisciplinary way and involving all stakeholders concerned [2]. Water governance is defined in this case as involving stakeholders to deal with water issues in an integrated way.

Increasing complexity and uncertainty in river basin systems have created land and water management problems, but the limited capacity of state institutions to deal effectively with such conditions suggests that the current system must be reformed and that a more powerful system-response capability founded on inter-organizational collaboration should be developed. Effective governmental and non-governmental collaboration would enable management problems to be dealt with in a more efficient, effective and equitable manner [3]. Countries should make the necessary efforts to obtain effective participation in the planning and decision-making process of water resources management involving users and public authorities [4].

According to Foerster [5] three central components of purposeful and adaptive institutional innovation for environmental water governance have to be addressed, namely developing processes to reach an ecologically sustainable allocation of water resources, using instruments to provide for and protect water and finally the development of management frameworks for rivers with environmental water regimes.

The challenge of making central requirements work effectively at local levels is a common problem for environmental governance throughout the world and a reason to put China's experience in an international perspective. China's problem is not the absence of environmental laws, but the challenge of making them work [6]. This paper will compare the water environmental pollution conditions and the governance systems of the Tai and Chao Lake Basin and learn from experiences elsewhere in the world. The objective is to analyze the water pollution and environmental governance problems. The situation in China will be compared with other countries, in particular Canada, France, the United Kingdom (UK) and the United States (US). The objective is to suggest governance policies for freshwater lakes, which are under pressure. We will argue that China emphasizes technical solutions for water management and does not pay sufficient attention to governance issues. The research question is how does China deal with lakes in governance terms and how does this compare to international practices such as more participatory water governance, and unified leadership of and well specified rules for 
different organizations involved?

\section{General Situation in the Tai and Chao Lake Basin}

\subsection{Natural and Social Conditions}

The Tai lake is a large shallow lake and part of the river network in the Yangtze River Delta plain. The shoreline around the lake has a total length of $405 \mathrm{~km}$ and an average depth of $1.89 \mathrm{~m}$. The Tai Lake serves as a natural water reservoir, the most important water source for surrounding regions. The area of the Tai Lake basin is $33,700 \mathrm{~km}^{2}$, and the water area is $2338 \mathrm{~km}^{2}$ (2010). In terms of administrative divisions, the whole area of the Tai Lake basin is divided over three provinces and one city: Jiangsu Province (52.6\%), Zhejiang Province (32.8\%), Shanghai City (14.0\%) and Anhui Province (0.6\%).The Tai Lake basin is one of the most developed areas in China, and has produced $10.8 \%$ of China's total GDP with $0.4 \%$ of China's land area and $4.3 \%$ of China's population. Its per capita GDP was about 2.5 times China's average per capita GDP in 2010 [1].

The Chao Lake is located in the centre of Anhui Province, on the left bank of the lower reaches of the Yangtze River with a lake area of $760 \mathrm{~km}^{2}$ and a total basin area of 13,500 $\mathrm{km}^{2}$. The Chao Lake basin belongs completely to the administrative divisions of Anhui Province. 33 Rivers flow into the Chao Lake, and eight main tributaries flow into the Chao River and then flow into the Yangtze River through the Yuxi River in the west. The Chao Lake Basin has an average annual surface water content of 5.36 billion $\mathrm{m}^{3}$ with an annual average of 3.49 billion $\mathrm{m}^{3}$ flowing into it.

In 2010 the population in the Chao Lake basin was about 10.6 million, 5.7 million of which live in the urban areas. The urbanization rate is $54 \%$. The Chao Lake basin is a pivot area of Anhui province. Due to a multiple operation structure of combined plantation, aquatic breeding and animal husbandry its agriculture is well developed. Its industry is mainly based on machinery, electronics, chemical industry, metallurgy, textile, food processing and building materials. The GDP reached about 335.9 billion RMB, while the GDP per capita is 32,000 RMB, lower than the national average level; the importance of the agricultural, industrial and service sectors is $17.4 \%, 47.0 \%$, and $35.6 \%$ [7]. The major natural and economic indicators of the Tai and Chao Lake basins are summarized in Table 1.

\subsection{Water Pollution Conditions}

According to Surface Water Environment Quality Standard (GB3838-2002), the water quality of Tai Lake was Class I II in the 1960s and Class II in the 1970s. At the end of the 1980s, the water quality further degraded from Class IV to Class V, and even to Below Class V (worse than Class V) in the period from the end of the 1990s to early 2003 [8]. With heavy pollution, particularly of the water in the bays, the Tai Lake is currently included in the list of the most seriously polluted rivers and lakes in China. A massive appearance of algae in May 2007 degraded the water quality at the drinking water intake spot for Wuxi City in the Meiliang Bay, causing a water shortage supply. The toxic-algae bloom in the Tai lake basin made headlines around the world at the end of 2014.

Rapid economic development quickly gave rise to an increase in pollution emissions. The industrial pollution in Tai Lake stems mainly from the textile printing and dyeing industry, the chemical raw materials and chemical products manufacturing, the food manufacturing, etc. A large number of industrial enterprises with low-technology and serious pollution have been transferred to rural areas where there is relatively weak supervision and it is even more difficult to control industrial pollution. Hence a lot of industrial pollution enters the Tai Lake through the rivers. The proportion of non-point source pollution is also increasing in the Tai Lake area. For

Table 1. Comparison of social and economic status between the Tai and Chao Lake basin (2010).

\begin{tabular}{|c|c|c|c|c|c|}
\hline Basin & Socioeconomic status & Administrative region & Basin area $/ \mathrm{km}^{2}$ & Population/million & GDP/billion RMB \\
\hline $\begin{array}{c}\text { The Tai Lake } \\
\text { basin }\end{array}$ & State key economic zone & $\begin{array}{l}\text { Includes Jiangsu, Zhejiang, } \\
\text { Shanghai, and a little } \\
\text { area of Anhui }\end{array}$ & 33,700 & 34.8 & 3821 \\
\hline $\begin{array}{l}\text { The Chao Lake } \\
\text { basin }\end{array}$ & Local economic zone & $\begin{array}{l}\text { Belongs entirely to } \\
\text { Anhui Province }\end{array}$ & 13,500 & 10.6 & 336 \\
\hline
\end{tabular}


example, in the 1980s the proportion of total phosphorus (TP) increased from $78 \%$ to $87 \%$; the proportion of total nitrogen (TN) from $60 \%$ to $78 \%$ and the proportion of Chemical Oxygen Demand (COD) from 50\% to 63\% [1].

Already in the 1980s, the pollution load in the Chao Lake basin exceeded the carrying capacity of the water sources, and a series of environmental problems arose in 2010. Data from 28 monitoring sections in the rivers around the lake showed that $17.9 \%$ of the section water quality was class IV, and $35.7 \%$ was class V. The data from twelve conventional sections for water quality monitoring in Chao Lake indicated that $50 \%$ of the water was Class-IV, V and inferior Class V [9]. The overall water quality of Chao Lake has improved from moderate to mild eutrophication after the environmental management of the 11th Five-Year Plan.

The waste water discharge of the Chao Lake basin amounted to 400 million tons; among of them, of which industrial effluent accounted for $13.4 \%$, and urban sewage for $86.6 \%$, the COD was 176,000 tons, emission of ammonia and nitrogen was 14,000 tons [7].

\section{Governance Systems of the Tai and Chao Lake Basins}

\subsection{Pollution, the Background}

Since China's reform and opening up in 1978, it has achieved rapid industrialization and urbanization in the middle and lower reaches of the Yangtze and the Huai Rivers. At the same time waste dumping and polluted water have increased continuously. Environmental management could not keep up with the pace of economic growth, which is one of the most important causes of water pollution and eutrophication of the Tai and Chao lakes.

Environmental management of the Tai Lake basin is a typical trans-administrative water pollution problem, which mainly involves two provinces and one city. The Tai Lake Basin Authority was set up by the Ministry of Water Resources in 1984 to perform water resources coordination and management in the Tai Lake Basin, but its capacity of supervision and coordination is limited. The Tai Lake Basin Authority is not a powerful basin environmental management institution but a public institution with limited functions. It cannot play a leading role in water resources protection and water pollution control.

Prior to August 2011, the Chao Lake basin covered three cities, including Chao, Hefei and Lu'an. Moreover, the water environmental management departments involved water conservancy, environmental protection, urban construction, fishing, transport, tourism and other things. There was no unified management organization or coordination mechanism for a long time and the various regions and departments all pursued their own interest, which led to disorderly management. External diseconomies of water pollution are amplified due to scattered management of administrative districts and departments.

Another cause of serious water pollution is the current system of farming and aquaculture, which results in non-point source pollution. The five largest freshwater lake basins are not only the pivotal production areas of grain, cotton and oil, but also important areas for poultry farming and fish breeding. The agricultural non-point source pollution was caused mainly by fertilizer use. Especially nitrogen and phosphorus nutrient losses are an important factor leading to eutrophication.

The existing agricultural production mode has aggravated the non-point pollution. The internationally recognized standards of average chemical fertilizer use is no more than $22,500 \mathrm{~kg} / \mathrm{km}^{2}$ per year, whilst the average annual chemical fertilizer use in China in 2011 was 43,430 kg/ km² per year, which is 1.93 times the upper safety limit. When it rains, a lot of residual nitrogen is washed out through drainage network system into the lake. Furthermore the aquaculture surrounding the lake has also impaired the water quality, because the baits used by the fishers have become fertilizer for harmful algae, thus increasing eutrophication.

$30 \%$ of the water pollution in the Chao Lake comes from industrial wastewater and domestic sewage, and $70 \%$ from non-point source pollution. The non-point source pollution is greater than the point source pollution, and the main pollution components are nitrogen, phosphorus, nutrients and aerobic organisms. The reason for this is that pollution control of industrial wastewater and domestic sewage have received much attention, but the agricultural non-point source pollution control has not received enough attention [10].

Finally, reclaiming land from marshes and building sluices has restricted ecological functions. The rapid growth in population of the lake area has required more land. A large-scale reclamation activity was started in the middle and lower reaches of the Yangtze and Huai rivers in the 1950s. The water areas decreased about $13,000 \mathrm{~km}^{2}$, which amounted to 1.3 times the total area of the present five freshwater lakes. Also, it reduced the 
lake's water volume by 50 billion $\mathrm{m}^{3}$, which amounted to 1.2 times the total volume of the present five freshwater lakes [10]. The reclamation has caused a sharp shrinking of the lake area, reduction of the environmental capacity of the ecosystem functions and of the purification abilities, which has accelerated the lake's eutrophication.

In China water management often implies looking for technical solutions to deal with the problems. However, building sluices and dams discontinues the natural process of water exchange among the lakes and the large rivers, disrupting the cleansing circulation of fresh water and the development of biological diversity and they still need to be managed. Taking Chao Lake as an example, originally it was a semi-closed water body with many rivers flowing into the lake but only a single channel out to the Yangtze River. To meet the demands of urban water supply, shipping, agricultural irrigation, flood control and drought and so on, control projects have been initiated. For example, Yuxi Sluice is a large control sluice at the estuary of Chao Lake flowing into the Yangtze River, which was built at 1967 and has played an important role in flood control and irrigation. Since then the water volume exchanged between Chao Lake and the Yangtze River decreased by $88.2 \%$. The lake almost lost its original natural transfer capacity, which led to serious sediment deposition and the accumulation of pollutants, and aggravated eutrophication.

\subsection{Tai Lake Basin Governance System}

According to the Water Law of The People's Republic of China issued in 1988, the basic management system of water resources is a system of unified management, which combines hierarchical management and horizontal departmental management. The Water administration department under the State Council shall be in charge of the unified administration of water resources throughout the country. In 2002 the Amendments of the Water Law of the PRC (the New Water Law) made it clear that the state will apply the water resources management system through combining basin management (interpreted as dealing with the water's natural characteristics) with regional administrative management (dealing with the socio-economic environment). This is for the first time a legal recognition for "integrated basin management".

The Regulation for Administration of the Tai Lake Basin was put in place on November 1st 2011 after it was accepted by theStanding Committee of the State Council of the People's Republic of China. The Regulation indicates that water resources management system is a "combination of basin management with departmental management and regional management" and that "the Nation is responsible for establishing coordination mechanisms and making overall arrangements of major issues in the Tai Lake basin management”. According to these laws and regulations, the water environmental governance system in the Tai Lake basin includes four important institutions (Figure 1), which do not always collaborate.

\subsubsection{The Ministry of Water Resources or the Department of Water Administration}

Article 12 of the New Water Law stipulates: The department of water administration of the State Council is responsible for the integrated administration and supervision of the nationwide water resources. Article 5 of the Regulation for Administration of the Tai Lake Basin (2011) reads: The Tai Lake Basin Authority should perform the supervision and administration endowed by the laws, administrative regulations and the departments of water administration of the State Council under the leadership of the Ministry of Water Resources. Thus the Tai Lake Basin Authority is the resident agency of the Ministry of Water Resources.

Moreover, The Water Resources Protection Bureau of Tai Lake Basin performs the administrative responsibility for water resources protection and water pollution control. It is under the double jurisdictions of the Ministry of Water Resources and the Ministry of Environmental Protection, and its administrative position is one level below the Tai Lake Basin Authority.

\subsubsection{The Department of Environmental Protection}

Article 7 of the Environmental Protection Law states: the Department of Environmental Protection is mainly responsible for the integrated administration and supervision of environmental protection. Thus the Ministry of Environment Protection has been authorized to take care of water environmental management. The East China Environmental Supervision Centre performs the supervision and administration duties related to environmental protection in East China as the resident law enforcement and supervision agency of the Ministry of Environment Protection. 


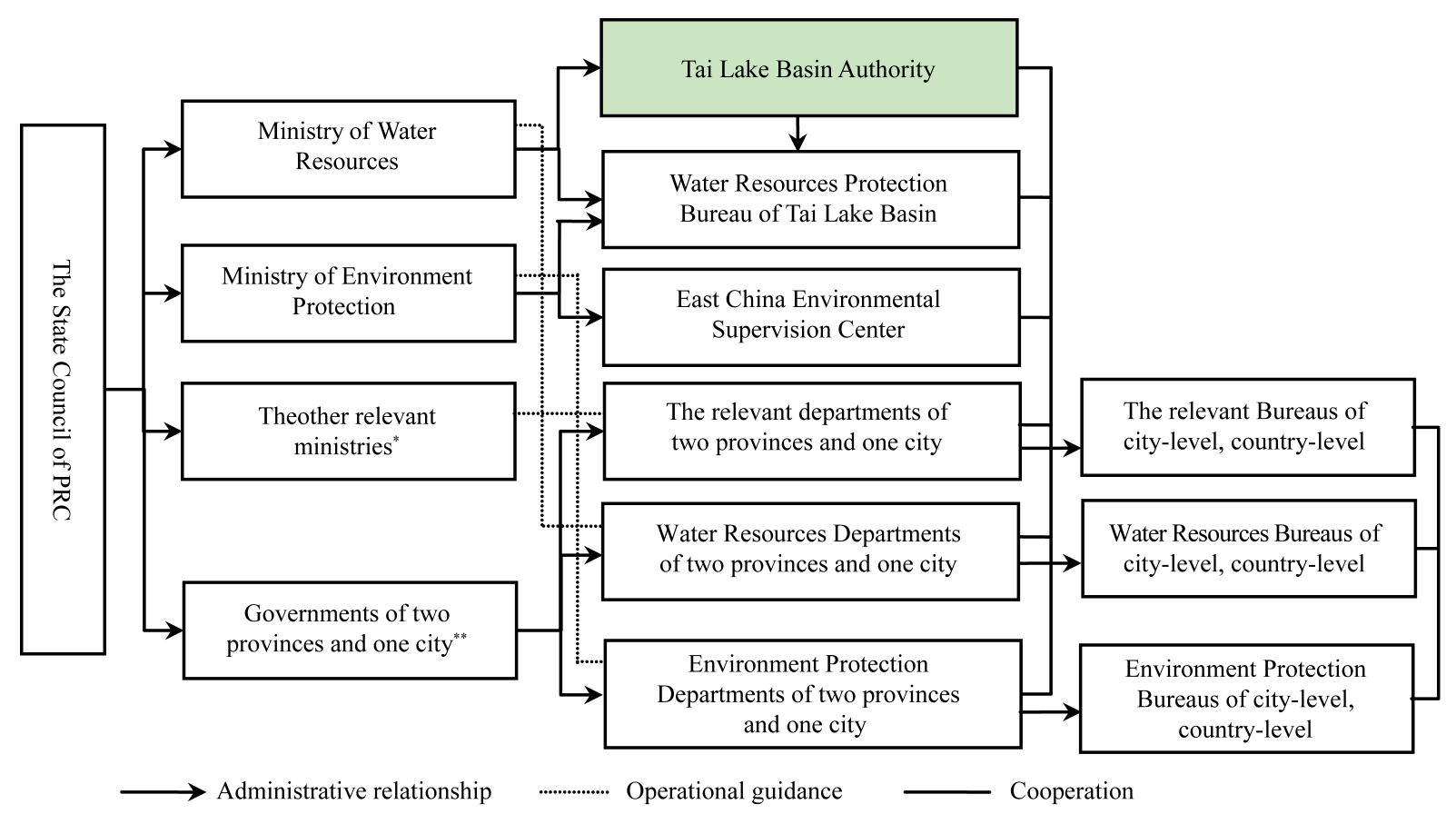

${ }^{\text {*T }}$ The other relevant ministries refer to agriculture, forestry, development and reform, fishery, tourism, and so on.

**Two provinces and one city refer to Jiangsu Province, Zhejiang Province, Shanghai.

Figure 1. Water environmental governance institutions of Tai Lake basin.

\subsubsection{Other Relevant Ministries}

Besides the Ministry of Water Resources and the Ministry of Environmental Protection, involved in managing of the water in the Tai Lake, the National Development and Reform Commission, the Ministry of Land and Resources, the Ministry of Agriculture, the Ministry of Forestry, the Ministry of Transport, the Ministry of Housing and Urban-Rural Development, and so on also perform these duties.

\subsubsection{Local Governments and Relevant Departments of the Two Provinces}

The relevant departments of local governments above the county level take charge of the administration of the Tai Lake basin in their own administrative regions according to the laws and administrative regulations. The responsibility and the evaluation system of local governments are focused on water resources protection and water pollution control in the Tai Lake basin.

Together these institutions have created a complicated governance system for the Tai Lake basin. Because the subjects of basin management and regional management belong to different institutional systems, the relation is not one of superior or subordinate but of equality as far as authority is concerned, which results in all kinds of difficulties in practice.

\subsection{Chao Lake Basin System}

Until August 2011 the Chao Lake basin had no unified management and no coordination mechanism existed. The environmental management of Chao Lake involved nearly ten departments, such as the department of environmental protection, water conservancy, development and reform, construction, agriculture, shipping and tourism, etc. Among them the departments of water conservancy, environmental protection and fishery carry out most of the work.

On August 22, 2011 the Anhui Provincial Government announced the abolishment of the Chao Prefecturelevel Municipality administration structure and reallocated the districts and counties under its administration to other prefecture level municipalities. The administrative restructuring aimed to create a greater Hefei Municipality, which will foster development in the region, which will simplify integrated management of the Chao Lake basin. 
The Chao Lake Administration Bureau was formally established on March 22012. According to the regulation in Opinions On Revocation of Chao City at Department Level and Adjustment of Part about Administrative Regions and Agencies Transfer and Staffing Placement [2011] 29 issued by the Anhui Provincial General Office, the Chao Lake Administration Bureau is an administrative institution of deputy department-level. It will manage the general affairs of Chao Lake as a whole, such as planning, water conservancy, environmental protection, fishery administration, navigation, tourism, and the major control facilities of the Chao Lake basin [11]. Since the establishment of the Chao Lake Administration Bureau is at its initial stage, there are some issues, such as the responsibilities of different levels of regional governments and the basin departments, which are not clear. Legislation and supporting regulation are lacking.

Similar to the governance system of the Tai Lake basin, the water environmental governance structure of the Chao Lake basin includes the department of water administration, the department of environmental protection, the other relevant ministries and the local governments and relevant departments of Anhui Province (Figure 2).

Major governance issues identified in the Chao Lake basin were scattered departmental management, and the need to establish coordination mechanisms among departments. Secondly, the pattern of regional segmentation, although improved in the Chao Lake basin, still requires further reforms. Finally, the basin management institution exists in name only, and the weak regional management capacity cannot achieve the management objectives. Carrying out the technical works is generally easy but managing the results is not.

\subsection{The Chao Lake Governance System}

The governance systems of the Tai and the Chao Lake basins represent the major water environmental governance mode of China. Water resources are state-owned, and the basin management system adopts a three-level structure of national ministries, basin administrations and regional departments. This is a combination of basin with departmental and regional management [12]. The lake basin governance system is slightly different from Lake Tai (cf. Figure 1 and Figure 2 and Table 2 and Table 3).

\subsubsection{National Ministries}

The Ministry of Water Resources is responsible for most of the water resources management functions, but mainly focuses on water quantity, whilst the Ministry of Environmental Protection mainly focuses on water quality management, as the authority responsible for environmental protection. The Ministry of Agriculture,

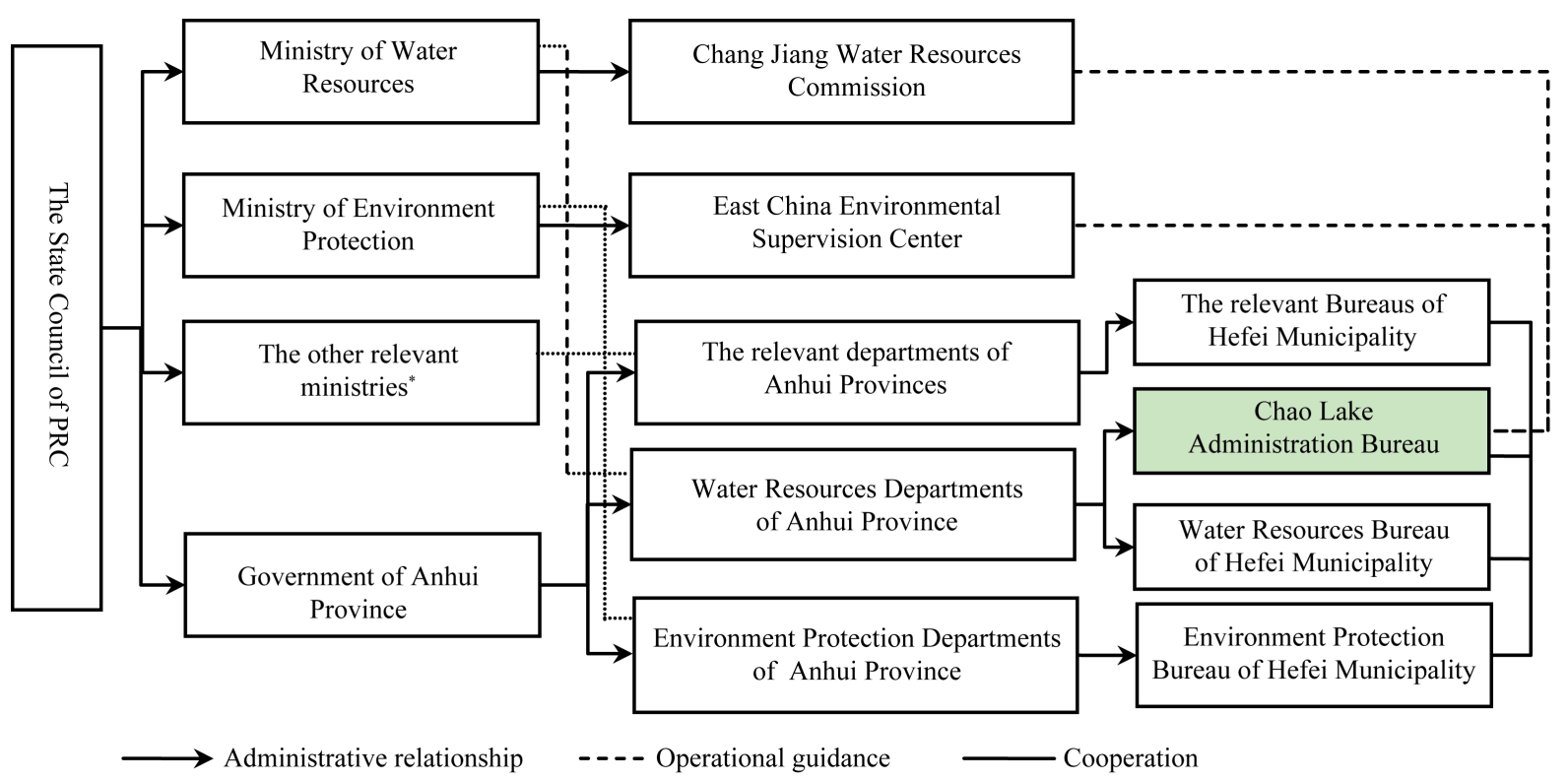

"The other relevant ministries refer to agriculture, forestry, development and reform, fishery, tourism, and so on. 
Table 2. Management system of water resources and environment.

\begin{tabular}{cl}
\hline \multicolumn{1}{c}{ Ministries } & \multicolumn{1}{c}{ Main Functions } \\
\hline Ministry of Water Resources & $\begin{array}{l}\text { Unified management of water resources, river management, flood control, water } \\
\text { and soil conservation, management of hydraulic engineers }\end{array}$ \\
Ministry of Environment Protection & $\begin{array}{l}\text { Water quality management, prevention and control of water pollution, water } \\
\text { quality monitoring, water pollution source monitoring }\end{array}$ \\
National Development and Reform Commission & Water resources development, planning of ecological environment construction \\
Ministry of Agriculture & $\begin{array}{l}\text { Non-point pollution control, protection water environment of fishery and aquatic } \\
\text { wildlife habitats }\end{array}$ \\
Ministry of Forestry & $\begin{array}{l}\text { Watershed ecology, protection and management of water conservation forests, } \\
\text { wetland management }\end{array}$ \\
Ministry of Land and Resources & $\begin{array}{l}\text { Land resources management, monitoring and supervising the excessive mining } \\
\text { and pollution of groundwater }\end{array}$ \\
Ministry of Transport & River navigation, marine pollution control \\
Ministry of Housing and Urban-Rural & Project planning for urban water supply, drainage and sewage treatment \\
\hline Development &
\end{tabular}

\section{Table 3. Assessment of functions of water environment governance between the Tai and Chao Lake basin.}

\begin{tabular}{|c|c|c|c|}
\hline \multicolumn{2}{|c|}{ Functions } & The Tai Lake basin & The Chao Lake basin \\
\hline \multirow{2}{*}{$\begin{array}{l}\text { Decision } \\
\text { making }\end{array}$} & Agencies & $\begin{array}{l}\text { The Nation is responsible for making overall } \\
\text { arrangements of major issues in the Tai Lake } \\
\text { basin management, and the Ministry of } \\
\text { Environment Protection works as the major } \\
\text { authority of environment protection. }\end{array}$ & $\begin{array}{c}\text { The government of Anhui Province and } \\
\text { Chang Jiang Water Resources Commission } \\
\text { are responsible for water resource } \\
\text { management and water environmental } \\
\text { protection of the Chao Lake basin. }\end{array}$ \\
\hline & Legal guarantee & $\begin{array}{c}\text { The Regulations for Administration of } \\
\text { the Tai Lake Basin were put in place on } \\
\text { November 1st } 2011 \text {. }\end{array}$ & $\begin{array}{l}\text { The Revised Regulations on Water Pollution } \\
\text { Control of Chao Lake Basin were implemented } \\
\text { on } 1^{\text {st }} \text { December, } 2014 \text {. }\end{array}$ \\
\hline \multirow[t]{2}{*}{ Execution } & $\begin{array}{l}\text { Implementation of } \\
\text { policy and plan }\end{array}$ & $\begin{array}{c}\text { Due to lack of effective enforcement means } \\
\text { and efficient authority, the actual power } \\
\text { of the Tai Lake Basin Authority to deal } \\
\text { with water pollution is limited. }\end{array}$ & $\begin{array}{l}\text { The three departments of water conservancy, } \\
\text { environmental protection and fishery undertake } \\
\text { major activities. It is difficult for the Chao } \\
\text { Lake Administration Bureau to implement } \\
\text { an effective management system. }\end{array}$ \\
\hline & $\begin{array}{l}\text { Enforcement } \\
\text { Agency }\end{array}$ & No special enforcement agency & No special enforcement agency \\
\hline Supervision & $\begin{array}{l}\text { Enforcement } \\
\text { capacity and } \\
\text { power }\end{array}$ & $\begin{array}{l}\text { It is to inspect comprehensive treatment for } \\
\text { key areas and rivers, as well as regularly } \\
\text { supervise performance of each member } \\
\text { unit of the Provincial Committee } \\
\text { of Tai Lake Pollution control. }\end{array}$ & $\begin{array}{c}\text { Lack of law support and } \\
\text { public participation }\end{array}$ \\
\hline \multirow[t]{2}{*}{ Coordination } & $\begin{array}{l}\text { Department } \\
\text { coordination }\end{array}$ & $\begin{array}{l}\text { The Nation is responsible for establishing } \\
\text { coordination mechanism. Joint Conference at } \\
\text { Province and Ministry Level for comprehensive } \\
\text { treatment of Water environment in Tai Lake } \\
\text { basin has been established. }\end{array}$ & $\begin{array}{l}\text { There is no special department } \\
\text { coordination mechanism. }\end{array}$ \\
\hline & $\begin{array}{l}\text { Regional } \\
\text { coordination }\end{array}$ & $\begin{array}{l}\text { Jiangsu Province, Zhejiang Province } \\
\text { and Shanghai all set up their relevant } \\
\text { coordination organizations. }\end{array}$ & $\begin{array}{l}\text { The main problem is existing separate } \\
\text { management of "the lake and rivers" } \\
\text { of Chao Lake. }\end{array}$ \\
\hline
\end{tabular}


Ministry of Transport, National Development and Reform Commission and other departments respectively undertake the management functions of fishery resources, wetland, groundwater, etc. [13].

\subsubsection{Basin Administrations}

The Tai Lake Basin Authority performs basin management duties as the resident agency of The Ministry of Water Resources. Its duties on environmental protection are protecting water resources of the Tai Lake basin, partitioning water environmental function areas, examining water environmental carrying capacity, establishing a total pollution control plan, monitoring water quantity and water quality at the provincial boundaries, in important water areas and in case of inter-basin water transfers.

The Chao Lake belongs to the river network of the Yangtze River basin, so the Chang Jiang Water Resources Commission is responsible for water resource management and water environmental protection of the Chao Lake basin.

\subsubsection{Regional Administrative Departments}

Regional water resources departments and other relevant departments undertake and implement the specific functions of river basin management which are endowed by the central government. The departments have a presence at the province, city and county level. For the Tai Lake basin this includes the water resources, environmental, and other relevant departments of Jiangsu Province, Zhejiang Province and Shanghai. For the Chao Lake basin it includes the relevant departments of the Anhui Province and the Hefei Municipality. How the four functions work in the Tai and Chao Lake Basins is analysed in the following section, based on Table 3.

\section{Governance Problems Analysis in China and International Experiences}

\subsection{Conflict of River Basin and Administrative Management}

Although the Tai Lake basin has made some progress with integrated water resources governance since the 1980s, there is still a long way to go to improve the water governance system and coordination mechanisms. In the Chao Lake basin, the integrated water resources governance system is still at an early stage. The Chao Lake Administration Bureau was only set up in 2012, but it is not yet a lake basin management institution. Taking the examples of the Tai and Chao Lake basins, we will analyse water pollution and environmental governance problems.

As stipulated in Article 12 of the New Water Law, water resources management for river basin integrates regional administrative management in China. But river basin and regional management are different as concerns the units concerned and their objectives. The basin management regards the river basin as the unit to manage water resources, and its objective is to make overall effective utilization of the basin water resources. Regional management is based on the administrative district as the unit and its goal is to make comprehensive utilization of water resources to achieve regional economic development. The different administrative districts in the basin are more concerned with their own interests focusing only on economic growth, which causes constant conflicts between the local government and the basin management institution. The former represents the local economic interests and the latter represents the interests of the entire basin. Under the current management structure, the level of the basin management institution is significantly lower than the level of local government, whatever its authority or administrative power, so it is difficult for it to achieve the implementation functions of the basin management institution [14].

\subsection{A Comparison with the Federal Environmental Protection Agency in the US}

In the Chao Lake basin, the basin management institution depends strongly on the local government for the funds and personnel, so it is difficult to carry out its role. To the contrary environmental watershed management in the United States is carried out in a relatively centralized system under unified leadership. Between the federal and local agencies, power is mainly concentrated in the federal agency and among the federal agencies; power is concentrated in the federal environmental agency. Regional offices in various environmental protection areas are set up by the Federal Environmental Protection Agency (EPA) to exercise power on behalf of EPA. The EPA is responsible for formulating relevant regulation, providing specifications and standards as well as benchmarks, and supervising the implementation of other relevant institutions. The EPA has a special power, 
that is, it can replace other institutions and implement supervision and disciplinary measures for illegal activities under certain circumstances.

\subsection{Absence of Powerful Execution Agencies in River Basin Management}

For a long time, the basin administration agencies in China were responsible for the formulation of overall basin utilization plans and relevant professional plans, but power of authority for supervision and implementation of the plans is not clearly specified. Since no clear legal guarantee or responsibilities exist, the basin agency cannot receive recognition and support from other departments when performing its duties, so its roles are far from what they should be.

The Tai Lake Basin Authority was set up for example by The Ministry of Water Resources in 1984 to perform water resources coordination and management in the Tai Lake Basin, but its capacity of supervision and coordination is limited by its defined responsibilities and legal status. It is not a powerful basin environmental management institution but a public institution with administrative functions, and does not play a leading role in water resources protection and water pollution control. When dealing with an acute water pollution incident, the Ministry of Environment Protection will be in the forefront, while the basin management institution just implements policies without having decision-making authority. It only reports to its superior, the Ministry of Water Resources, which puts the basin management agency in a passive position.

\subsection{A Comparison with the Thames Water Authority in the UK}

International experience shows that a powerful river basin management institution with comprehensive decision-making and coordination mechanisms should be built for integrated basin administration [15]. For example, the Thames Water Authority was created in the United Kingdom in 1975. It brought together all the water management functions of the region in one public body to strengthen the macro-management of central government [16].

\subsection{Poor Coordination of the Departments}

The coordination of the departments is a big issue under the existing water environmental governance system. There are water related laws and regulations in water administrative departments, in environmental protection departments, and other departments such as agriculture, fishing as well as shipping. Considering their own interest, these departments make regulations on their own without a coordination mechanism, which leads to conflicting legislation. For example, the Department of Environment Protection made a Plan for Water Environmental Protection and a Plan for Prevention and Control of Water Pollution, while the Department of Water Resources made a Plan for Water Resource Protection, and the Department of Environment Protection issued the Water Environment Functional Zoning, while the departments of water resources issued the Water Functional Regionalization. Due to the conflict of interests and the lack of communication, the evaluation standards of water environment and water quality adopted by each department are different, so the water quality information and the amount of pollution emission released by each department are different, which seriously damages the government's credibility.

\subsection{A Comparison with Coordination in Canada}

Canada issued regulations and systems about the protection of ocean environment, which clarify the governance structure by specifying the responsibilities, status, rights of the relevant institutions, and the relationships with local governments. It attaches great importance to the comprehensive management patterns in legislation so as to avoid many problems.

\subsection{Unsound Supervision Mechanism and Public Participation}

Presently the supervision mechanism of China's water environmental governance system has many shortcomings. There is no special enforcement institution in the basin management system, nor does the law have clear rules allowing the system to discipline those who do not fulfil their duties. Especially the environmental protection supervision and management personnel tend to abuse their powers and to neglect their duties. 
The public are the direct victims once the water environment is polluted, so the public deserves to participate in decision-making and supervision mechanisms. However, public participation is missing, and there are few ways and channels to obtain environmental information for the public, which leads to a low citizen's awareness of water quality degradation.

\subsection{Public Participation Mechanisms in France and the US}

More and more countries are actively introducing public participation mechanisms in water environment protection. In the United States, many feasible roads have been taken to encourage the public to participate at federal, state and local levels, including public hearings, large public meetings, public committees and so on. The government cannot make any major decisions without consulting public opinion. In France, the river basin commission is comprised of experts, voters and user representatives, each of whom account for a third of the "ThreeThirds” System. This management pattern not only considers the council's authority and professional inputs, but also fully meets the citizen's right to know, which greatly improves the efficiency of river basin environmental management.

\section{Conclusions and Policy Suggestions}

Comparing how other countries deal with polluted lakes it comes out that the emphasis in China is too much on looking for technical solutions, rather than improving the governance systems for these lakes. The trends in international water management are from regional to river basin management and from decentralized to unified management. Learning from the experiences of foreign management of water pollution control, the feasible reform of the current river basin management system in China is still basing the management system on the government hierarchy, which integrates departments and regions, and deals with the conflicts among different departments and regions in the river basin by means of rebuilding organizations, improving coordination mechanisms and more legislation. The international practices suggest unified leadership, creating an integrated basin management institution or defining more precisely the specified responsibilities of the institutions involved in water governance.

Based on the above discussion and analysis, we would suggest the following policy suggestions for the water environmental governance in China, especially for the Tai and Chao Lake basin.

\subsection{Improve the Authority of Basin Management Agency}

Water environmental management in the Tai Lake basin is a typical trans-administrative pollution problem. So the Tai Lake Basin Authority should be elevated to the level of resident agency of the State Council of the PRC higher than the administrative regions. It would then be responsible for formulating the laws and regulations of water environment governance in each administrative region, free from any interference by local governments.

In the Chao Lake basin, it is necessary to define the legal status of the Chao Lake Administration Bureau as the central Chao Lake management agency, which shouldbe responsible for pollution control, resource protection and ecological construction within Chao Lake Basin. It should exercise the relevant supervision and management and administrative enforcement duties related to water conservancy, environmental protection, land and resources, transportation, forestry, agriculture, and fisheries, etc.

\subsection{Strengthen the Organization Structure of Basin Administrations}

To achieve integrated basin management, we suggest an organization structure of basin administrations with decision-making, implementation, supervision, and coordination functions.

1) The basin decision-making and coordination agency will be the highest authority. The great and significant river basins which concern national sustainable development should be directly managed by the Central Government, such as the Tai Lake Basin. Its members should include the directors of governments and departments, the heads of the administrative regions in basin, and a number of water user representatives. Its main function would be to formulate policy and mid-long term basin plans, schemes of water resource utilization and pollution emission of administrative regions. Additionally, it should handle basin water disputes and environmental pollution, and coordinate the departments of environmental protection, water conservancy, fishery and construction and to provide information. 
2) There should be a basin executive agency in charge of the routine work of basin management. Its members should consist of management staff and experts with practical experience. Its main function would be to be responsible for the specific water matters of the basin, including a regular release of information concerning the water quality of each monitoring section. The water resources management sectors and environment protection sectors of provinces, cities and counties in the basin are only responsible for carrying out the schemes of water resource utilization and pollution emission transmitted by the basin executive agency.

3) The Basin supervisory agency must be an independent body, with as its main function the monitoring and evaluation of the effects of the basin management institutions, implementing national laws and relevant policy, basin planning, etc.

\subsection{Improve Laws and Regulations System of Basin Management}

The government needs to strengthen water resources management laws. Although the department of water administration understands the importance of basin management from the successful experiences of foreign basin management, the New Water Law has chosen for a "combination of basin management with administrative region management”, where there is no clear definition of Basin Management in the existing laws.

It therefore follows that we require a special law on Basin Management redefining the nature of the river basin administrative institutions, which should be independent of the administrative system. The law should endow the basin institution with an independent legal status and clear duties; expand the functions and powers of the river basin administrative institution to all aspects of the basin water pollution prevention and control; refine the duties of all levels of governments in water resources protection work and clarify the legal relationship and responsibilities between the river basin administrative institutions and government water administration departments.

\subsection{Enhance Public Participation Mechanism}

The following three communication rules are needed particularly to improve public participation in water environment administration. Firstly, respecting the public's right to know, establishing an effective information platform and releasing information timely, making the public understanding the water pollution situation, the plan and measures, etc. Basin management institutions should publicize the decision-making process and the relative information regularly.

Secondly, establishing good communication channels, forming a basin management committee composed of the public, the governments and the water management departments, asking the public to participate in decisionmaking, to reflect their own opinions with a desire to protect their own rights and interests, etc.

Thirdly, pay more attention to the functions of public supervision and to public opinions on environmental policy implementation.

\section{Acknowledgements}

This project is supported by the Major project of National Social Sciences Fund of China (Grant No.12\&ZD214). In particular, we are thankful to the Tai Lake Basin Authority and the Chao Lake Administration Bureau for providing us with essential information.

\section{References}

[1] Gao, J. and Jiang, Z. (2012) Conservation and Development of China’s Five Largest Freshwater Lakes. Science Press, Beijing.

[2] Van Dijk, M.P. (2012) Introduction. International Journal of Water, 6, 137-154. http://dx.doi.org/10.1504/IJW.2012.049493

[3] Watson, N. (2004) Integrated River Basin Management: A Case for Collaboration. International Journal of River Basin Management, 2, 243-257. http://dx.doi.org/10.1080/15715124.2004.9635235

[4] Salman, S.M.A. and Bradlow, D. (2006) Regulatory Frameworks for Water Resources Management: A Comparative Study. The World Bank, Washington DC. http://dx.doi.org/10.1596/978-0-8213-6519-9

[5] Foerster, A. (2011) Developing Purposeful and Adaptive Institutions for Effective Environmental Water Governance. Water Resource Management, 25, 4005-4018. http://dx.doi.org/10.1007/s11269-011-9879-x 
[6] Guttman, D. and Song, Y. (2007) Making Central-Local Relations Work: Comparing America and China Environmental Governance Systems. Frontiers of Environmental Science Engineering in China, 1, 418-433. http://dx.doi.org/10.1007/s11783-007-0068-3

[7] Ge, C. and Cao, Y. (2012) Institutional Study on Chao Lake Integrated Water Environmental Management. EARD, Asia Development Bank.

[8] Jiao, C. (2010) The Present State and Challenges of Watershed Governance in China: A Study of Cases in the Taihu Lake Basin. Journal of Kobe University Law, 39, 325-358.

[9] Nie, J. and Chen, H. (2012) Opportunities and Challenges of Chao Lake Water Pollution Control after the Administrative Division Adjustment. Chinese Journal of Environmental Management, 4, 35-38.

[10] Jin, G. and Gao, C. (2008) Ecological and Environmental Problems of the Chao Lake and Countermeasures. Journal of Yangtze River, 39, 80-82.

[11] Zhang, H. and Cao, S. (2012) Anhui Province Performs Governance Strategy for Chao Lake. Environmental Protection, 18, 59-61.

[12] Van Dijk, M.P. and Liang, X. (2012) Beijing, Managing Water for the Eco City of the Future. International Journal of Water, 6, 270-289. http://dx.doi.org/10.1504/IJW.2012.049500

[13] Xia, J., Liu, X. and Li, H. (2009) Comparison of the Basin Management between the Murray-Darling Basin and Huaihe River Basin. Resource Science, 31, 1454-1460.

[14] Qian, Y. and Liu, Y. (2010) Study on Watershed Environmental Governance in China. Ecological Economy, 1, 162165.

[15] Shen, D., Wang, H. and Jiang, Y. (2004) Riverbasin Management Organization: An International Comparison and Suggestion on China. Journal of Natural Resources, 19, 86-95.

[16] Shi, H. (2009) Comparative Analysis of Water Pollution Governance of Thames River Basin and Taihu Basin. Water Resources Protection, 25, 90-97.

\section{Legislation}

Water Law of The People’s Republic of China 1988 http://www.chinawater.net.cn/law/WaterLaw.htm

Amendments of Water Law of The People's Republic of China (New Water Law) 2002

http://www.chinawater.net.cn/law/WaterLaw.htm

Environmental Protection Law of The People's Republic of China 1989

http://www.chinabaike.com/law/zy/xf/cw/1331164.html

The Regulations for Administration of the Tai Lake Basin 2011

http://law.lawtime.cn/d684161689255_1_p1.html

Opinions on Revocation of Chao City at Department Level and Adjustment of Part about Administrative Regions and Agencies Transfer and Staffing Placement 2011 